13. Методические указания по проведению гематологического обследования рыб. №13-4-2/1487. М.: Минсельхозпрод России, 1999. 20 с.

14. Строганов Н.С. Экологическая физиология рыб. М.: Изд-во АН СССР, 1962. 443 с.

15. Металлов Г.Ф. и др. Биохимические и морфофизиологические показатели русского осетра в современных экологических условиях Волго-Каспия // Тепловодная аквакультура и биологическая продуктивность водоемов аридного климата: матер. междунар. симпозиума. Астрахань: Изд-во АГТУ, 2007. С. 484-486.

16. Металлов Г.Ф., Гераскин П.П., Аксенов В.П. Физиолого-биохимические аспекты оценки рыбоводного «качества» самок севрюги Acipenser stellatus
(Pall.) // Аквакультура: проблемы и достижения / Инф. пакет. Сер. Аквакультура. 1997. Вып. 7. С. 4-14.

17. Пучков Н.В. Физиология рыб. М.: Пищепромиздат, 1954. 370 с.

18. Денисенко О.С. Эффективность использования бета-каротина в составе комбикормов для осетровых рыб: дис. ... канд. биол. наук. М., 2005. 198 с.

19. Артеменков Д.В., Макашова Т.А. Анализ морфологических и биохимических показателей клариевого сома (Clarias gariepinus) при выращивании в УЗВ с использованием пробиотика Субтилис // Современные проблемы и перспективы рыбохозяйственного комплекса. М.: ВНИРО, 2011. С. 4-7.

20. Самсонова М.В. Аланин- и аспартатаминотрансферазы как индикаторы физиологического состояния рыб: дис. ...канд. биол. наук. М., 2002. 166 с.

\title{
THE EFFECT OF PROBIOTIC DIET ON HEMATOLOGY AND PISCICULTURAL PARAMETERS OF YEARLING HYBRIDS OF RUSSIAN AND SIBERIAN STURGEON
}

(C) 2015

O.N. Gutsulyuk, postgraduate studentof department of water bioresourses and aquaculture Kuban State University, Krasnodar (Russia)

Abstract. In fish farming practices, stocking density is a key factor in determining the productivity and profitability of commercial fish farms. The use of probiotics as farm animal feed supplements increases the animal's growth and improve its health by increasing its resistance to disease. This study was undertaken to examine the effect of dietary probiotics on yearling hybrids of russian and siberian sturgeon, based on hematological profile and piscicultural performance. The experience was carried out in 4 groups (Control and Treatment). In Control group, probiotic was not applied in diet but in treatment groups, probiotics «Bacell», «Monosporin», and «Prolam» was administered in feed at a concentration of $2 \%$. As a result, a positive influence on growth performance and survival rate were assessed together with improvement of physiological status (based on hematological indices). Thus, probiotics addition to diet had the effect on erythrocyte count, hemoglobin, leucocyte count, percent of lymphocyte, serum total protein, percent of neutrophile and monocyte The results suggest that probiotics can stimulate immune parameters hybrids of russian and siberian sturgeon and can be successfully used in fishfarming.

Keywords: probiotics; hybrids of russian and siberian sturgeon; hematology indices; growth performance; juvenile; haemaglobine; erythrocytes; total protein.

УДК 577.118 (571)

\section{СОДЕРЖАНИЕ МИКРОЭЛЕМЕНТОВ У ЖИТЕЛЕЙ РАЗЛИЧНЫХ ЭТНИЧЕСКИХ ГРУПП МАГАДАНСКОЙ ОБЛАСТИ}

(C) 2015

H.B. Похилюк, соискатель кафедры биологии и химии

Северо-Восточный государственный Университет, Магадан (Россия)

\footnotetext{
Аннотация. В статье приводятся результаты исследования элементного статуса жителей различных этнических групп (коряки, эвены, метисы) Магаданской области. Методами атомно-эмиссионного и массспектрального анализов с индуктивно связанной плазмой определено содержание $\mathrm{Co}, \mathrm{Cu}, \mathrm{Fe}, \mathrm{Zn}, \mathrm{Si}, \mathrm{Al}, \mathrm{Cd}$, $\mathrm{Pb}, \mathrm{Sn}, \mathrm{Hg}$ в волосах. Отмечено незначительное отклонение содержания некоторых эссенциальных элементов (меди, железа, цинка) у аборигенов и метисов от среднероссийского уровня. Выдвинуто предположение, что указанное явление обусловлено адаптацией аборигенного населения к условиям Севера. Полученные низкие показатели тяжелых металлов - алюминия, кадмия, свинца, олова, кобальта, ртути свидетельствуют об относительном благополучии окружающей среды в плане загрязнения токсичными элементами. Повышенное содержание кремния в волосах аборигенов и метисов согласуется с данными о том, что Магаданская область является кремневой провинцией. Изменчивость большинства исследованных микроэлементов выше у метисов в сравнении с аборигенами. Высокая индивидуальная изменчивость содержания химического элемента может быть следствием дисбаланса элементов при дезадаптации организма к условиям окружающей среды или проявлением индивидуальных особенностей организма. Рассмотрены возможные последствия дефицита и избытка микроэлементов в организме коренных жителей Севера.
}

Ключевые слова: аборигены Севера, микроэлементы, адаптация. 


\section{Введение}

Большая часть площади Российской Федерации относится к северным территориям. Исследователи (Б.Б. Прохоров [1], В.И. Хаснулин [2] и др.) определяют Север как природную экстремальную зону, отличающуюся особыми природно-климатическими условиями и предъявляющую повышенные требования к адаптационным возможностям человека. Северные территории, согласно биогеохимическим картам В.В. Ковальского, бедны микроэлементами [3]. В ходе социальной и биологической адаптации аборигенного населения к природно-климатическим условиям Севера, происходившей на протяжении тысячелетий, сформировался экологический «портрет» северного этноса с рядом морфофизиологических признаков.[4].

В последние десятилетия намечается негативная тенденция в медико-социальном состоянии популяции аборигенов [5].Ввиду снижения показателя рождаемости, увеличения смертности, продолжительности жизни меньшей в сравнении со среднероссийскими показателями, высокой хронической заболеваемости, речь идет о вырождении коренных народов Севера. Для преодоления депопуляции аборигенов важно учитывать, с одной стороны, причины, приводящие к функциональным нарушениям в организме, с другой стороны - необходимо знать исходные параметры состояния здоровья коренных народов Севера (морфологические, функциональные, биохимические) [6].

Изменение культурного уклада жизни, структуры и качества питания, загрязнение среды проживания коренных жителей привело к нарушению поступления биологически активных веществ, в том числе витаминов и микроэлементов. Эндогенный избыток или недостаток микроэлементов может явиться предпосылкой нарушения обменных процессов и, при срыве компенсаторных механизмов, развития экологозависимых заболеваний (болезни щитовидной железы, иммунодефицитные состояния, анемия, гипертоническая болезнь) [7].

Целью работы явилось расширение представлений о микроэлементном «портрете» северной популяции аборигенных жителей Магаданской области.

\section{Материалы и методы}

Исследованы 108 коренных малочисленных жителей Северо-Востока России - студентов СевероВосточного государственного университета (СВГУ) в возрасте от 18 до 27 лет, организованно проживающих в Центре народов Севера СВГУ. Исследуемые были разделены на две группы: первая представлена аборигенными жителями - коряками, эвенами (50), вторая - метисами (58), рожденными от национальносмешанных браков европеоидов с представителями коренных этносов Севера.

Биологическим субстратом для элементного анализа послужили волосы. Считается, элементный состав волос отражает биогеохимическое окружение и коррелирует с концентрацией микроэлементов в крови [8].Спектральный анализ волос проведен в лаборатории АНО «Центр биотической медицины» г. Москва (аттестат аккредитации ГСЭН.RU.ЦОА.311, регистрационный номер в Государственном реестре POCC RU.0001.513118 от 29 мая 2003). Подготовка проб к анализу осуществлялась с использованием микроволнового разложения (Multiwave 3000, A.Paar), определение содержания химических элементов в образце проведено на приборах атомноэмиссионного (Optima 2000DV, PerkinElmerCorp) и масс-спектрального (ELAN 9000, PerkinElmerCorp) анализов с индуктивно связанной плазмой. Определено содержание следующих элементов: $\mathrm{Co}, \mathrm{Cu}, \mathrm{Fe}$, $\mathrm{Zn}, \mathrm{Si}, \mathrm{Al}, \mathrm{Cd}, \mathrm{Pb}, \mathrm{Sn}, \mathrm{Hg}$.

С помощью статистических методов проведен анализ полученных данных: определены максимальное (Max) и минимальное (Min) содержания химического элемента в волосах, размах изменчивости (Lim), pacсчитаны значения центильных интервалов (Р25-75), частоты отклонений уровня элементов от референтных значений концентраций химических элементов в волосах [9]. Расчеты значений и построения таблиц проведены с использованием программы Microsoft Excel.

\section{Результаты исследований и их обсуждение}

Общая характеристика элементного статуса. Как следует из данных, приведенных в табл. 1, значения центильных интервалов микроэлементов у метисов и аборигенов отклоняются от референтных значений. Наибольшие расхождения со значениями 25 и 75 центилей отмечены для токсичных, потенциально-токсичных и некоторых эссенциальных элементов. Низкие показатели тяжелых металлов: алюминия, кадмия, свинца, олова, кобальта, ртути указывают на относительное благополучие окружающей среды в плане загрязнения указанными элементами. Повышенные региональные центильные интервалы кремния у исследованных лиц подтверждают данные, согласно которым Магаданская область является кремневой геохимической провинцией [10].

Наименьшее расхождение с референтными значениями наблюдается у аборигенов и метисов в отношении железа, цинка, меди. Вероятно, это связанно с адаптационными перестройками в организме, направленными на поддержание указанных эссенциальных элементов на оптимальном физиологическом уровне.

Особенности статуса отдельных микроэлементов. Для более детальной оценки элементного статуса аборигенов и метисов нами проведено определение минимального и максимального значения содержания химического элемента в волосах, размах изменчивости (табл. 2).

Сравнение по группам микроэлементов позволило установить низкую изменчивость содержания кобальта, меди, железа, цинка, алюминия, кадмия, свинца, ртути у аборигенов и высокую - кремния, олова по сравнению с метисами. Большая индивидуальная изменчивость содержания химического элемента может быть следствием дисбаланса элемента при дезадаптации организма к условиям окружающей среды или проявлением индивидуальных особенностей организма. 
Н.В. Похилюк

СОДЕРЖАНИЕ МИКРОЭЛЕМЕНТОВ У ЖИТЕЛЕЙ...

Таблица 1 - Характеристика микроэлементного статуса аборигенных жителей Северо-Востока России

\begin{tabular}{|c|c|c|c|c|c|c|c|c|c|c|}
\hline \multirow{2}{*}{ 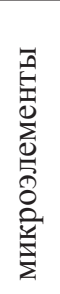 } & \multicolumn{2}{|c|}{$\begin{array}{c}\text { Референтные } \\
\text { значения }^{1}\end{array}$} & \multicolumn{4}{|c|}{ Аборигены, n=50 } & \multicolumn{4}{|c|}{ Метисы, n=58 } \\
\hline & $\begin{array}{l}\text { Р25, } \\
\text { мкг/г }\end{array}$ & $\begin{array}{l}\mathrm{P} 75, \\
\text { мкг/г }\end{array}$ & $\begin{array}{l}\text { Р25, } \\
\text { мкг/г }\end{array}$ & $\begin{array}{l}\text { Р75, } \\
\text { мкг/г }\end{array}$ & $\begin{array}{l}\text { Откло- } \\
\text { нение } \\
\text { Р25,\% }\end{array}$ & $\begin{array}{l}\text { Откло- } \\
\text { нение } \\
\text { Р75,\% }\end{array}$ & $\begin{array}{l}\mathrm{P} 25, \\
\text { Мкг/г }\end{array}$ & $\begin{array}{l}\text { Р75, } \\
\text { мкг/г }\end{array}$ & $\begin{array}{l}\text { Отклоне- } \\
\text { ние Р25 }\end{array}$ & $\begin{array}{c}\text { Отклоне- } \\
\text { ние Р75 }\end{array}$ \\
\hline \multicolumn{11}{|c|}{ Эссенциальные микроэлементы } \\
\hline $\mathrm{Cu}$ & 9,00 & 14,00 & 9,17 & 12,28 & $\uparrow 1,9$ & $\downarrow 12,3$ & 9,44 & 12,27 & $\uparrow 4,9$ & $\downarrow 12,4$ \\
\hline $\mathrm{Fe}$ & 11,00 & 24,00 & 9,39 & 15,86 & $\downarrow 14,6$ & $\downarrow 33,9$ & 11,62 & 21,76 & $\uparrow 5,6$ & $\downarrow 9,3$ \\
\hline $\mathrm{Zn}$ & 155,00 & 206,00 & 159,19 & 213,65 & $\uparrow 2,7$ & $\uparrow 3,7$ & 169,31 & 235,24 & $\uparrow 9,2$ & $\uparrow 14,2$ \\
\hline $\mathrm{Co}$ & 0,04 & 0,16 & 0,006 & 0,013 & $\downarrow 85,0$ & $\downarrow 91,9$ & 0,007 & 0,018 & $\downarrow 82,5$ & $\downarrow 88,8$ \\
\hline $\mathrm{Si}$ & 11,00 & 37,00 & 19,80 & 41,60 & $\uparrow 80,0$ & $\uparrow 12,4$ & 19,84 & 48,09 & $\uparrow 80,4$ & $\uparrow 30,0$ \\
\hline \multicolumn{11}{|c|}{ Токсичные и потенциально-токсичные микроэлементы } \\
\hline $\mathrm{Al}$ & 6,00 & 18,00 & 2,77 & 5,71 & $\downarrow 53,8$ & $\downarrow 68,3$ & 3,63 & 6,9 & $\downarrow 39,5$ & $\downarrow 61,7$ \\
\hline $\mathrm{Cd}$ & 0,02 & 0,12 & 0,01 & 0,03 & $\downarrow 50,0$ & $\downarrow 75,0$ & 0,006 & 0,03 & $\downarrow 70,0$ & $\downarrow 75,0$ \\
\hline $\mathrm{Pb}$ & 0,38 & 1,40 & 0,10 & 0,34 & $\downarrow 73,7$ & $\downarrow 75,7$ & 0,10 & 0,37 & $\downarrow 73,7$ & $\downarrow 73,6$ \\
\hline $\mathrm{Sn}$ & 0,14 & 0,66 & 0,04 & 0,11 & $\downarrow 71,4$ & $\downarrow 83,3$ & 0,04 & 0,13 & $\downarrow 71,5$ & $\downarrow 80,4$ \\
\hline $\mathrm{Hg}$ & $\begin{array}{c}\text { Нет } \\
\text { данных }\end{array}$ & $\begin{array}{c}5,0^{2} \\
\text { МКГ/Г }\end{array}$ & 0,28 & 0,65 & - & $\downarrow 87,0$ & - & 0,73 & - & $\downarrow 85,4$ \\
\hline
\end{tabular}

Примечание: ${ }^{1}$ - А.В. Скальный (2003); ${ }^{2}$ - биологически допустимый уровень (Таций Ю.Г., 2013); $\uparrow$ - повышенное содержание, $\downarrow$ - пониженное содержание элементов. $M е д b(\mathrm{Cu})$ - жизненно важный микроэлемент, участвующий в тканевом дыхании, процессах обмена веществ, входит в состав гормонов, является кофактором более 30 ферментов [7].Среди жителей многих регионов России распространен дефицит меди [11].

В ходе оценки содержания меди в волосах жителей исследованных групп, установлено, что изменчивость концентрации меди в волосах у метисов выше, чем у аборигенов $\left(\operatorname{Lim}_{2}=105,72>\operatorname{Lim}_{1}=26,90\right)$. В исследованных группах отклонение 25 и 75 центиля не выходит на пределы референтных значений, что указывает на адекватную обеспеченность организма метисов и аборигенов медью.

Цинк (Zn) требуется для синтеза белка (в геноме 3\% генов кодируют белки, связанные с цинком) [25], формирования костной ткани, функционирования десятков ферментов, некоторых гормонов (инсулина, дегидрокортикостерона), участвует в кроветворении, процессах регенерации, метаболизме алкоголя, играет важную роль в физиологии кожи и ее придатков, иммунном гомеостазе человека [12].

Нами показано, что изменчивость концентрации цинка в волосах у метисов выше, чем у аборигенов $\left(\operatorname{Lim}_{2}=872,74>\operatorname{Lim}_{1}=321,32\right)$.Отмечено повышение 75 центиля относительно референтных величин у метисов на $14,2 \%$ и у аборигенов на $3,7 \%$.

Избыток цинка проявляется нарушениями со стороны иммунной системы, поджелудочной железы, печени, кожи и ее придатков, диспепсическими расстройствами, приводит к снижению содержания в организме меди, железа и кадмия [13, с. 93].

Железо $(\mathrm{Fe})$ участвует в переносе кислорода, ферментативных реакциях, метаболизме холестерина, в обеспечении иммунных функций. Дефицит железа - один из наиболее распространенных пищевых дефицитов в мире [14, с. 5]. Считается, что на уровень железа в организме в значительной степени оказывают влияния климатические условия. В частности, воздействие низких температур приводит к снижению гемоглобина и развитию северной анемии [4].

Размах изменчивости содержания железа у метисов превышал аналогичный показатель аборигенов $\left(\operatorname{Lim}_{2}=63,36>\operatorname{Lim}_{1}=46,22\right)$. В группе аборигенов отмечено снижение 25 центиля $(14,6 \%)$, в группе метисов - 25 и 75 центили находятся в пределах референтных значений.

Проявления дефицита железа разнообразны: от латентных состояний до тяжелых состояний, сопровождающихся повреждениями тканей и органов, вплоть до летального исхода [7].

Кобальт (Со) участвует в окислительно-восстановительных реакциях, биосинтезе миелина, в процессах утилизации токсичных элементов, влияет на синтез белка. Для протекания гемопоэза необходимым условием является нормальное взаимодействие кобальта, меди и железа. Изменчивость концентрации кобальта в волосах у метисов выше, чем у аборигенов $\left(\operatorname{Lim}_{2}=0,077>\operatorname{Lim}_{1}=0,034\right)$, снижения 25 центиля у аборигенов составляет $85,0 \%$, у метисов $-82,5 \%$.

Поданным литературы, дефицит кобальта в организме может сопровождаться вегетососудистыми нарушениями, анемией, снижением памяти, общей слабостью [13].

Кремний (Si) влияет на образование костной ткани и коллагена и на обмен липидов, входит в состав соединительной ткани. Таежно-лесная зона, составляющая основную часть северных территорий, 
Таблица 2 - Концентрации микроэлементов в волосах аборигенных жителей Северо-Востока России

\begin{tabular}{|c|c|c|c|c|c|c|}
\hline \multirow{2}{*}{$\begin{array}{c}\text { Микроэле- } \\
\text { менты }\end{array}$} & \multicolumn{3}{|c|}{ Аборигены, n=50 } & \multicolumn{3}{|c|}{ Метисы, n=58 } \\
\hline & Min, мкг/Г & Max, мкг/Г & $\operatorname{Lim}_{1}$, мкг/Г & Min, мкг/кг & Max, мкг/Г & $\operatorname{Lim}_{2}$, мкГ/Г \\
\hline \multicolumn{7}{|c|}{ Эссенциальные микроэлементы } \\
\hline $\mathrm{Cu}$ & 3,68 & 30,58 & 26,90 & 5,86 & 111,58 & 105,72 \\
\hline $\mathrm{Fe}$ & 2,44 & 48,66 & 46,22 & 6,23 & 69,59 & 63,36 \\
\hline $\mathrm{Zn}$ & 93,19 & 414,51 & 321,32 & 83,26 & 956,00 & 972,74 \\
\hline Co & 0,001 & 0,035 & 0,034 & 0,003 & 0,08 & 0,077 \\
\hline $\mathrm{Si}$ & 7,82 & 217,01 & 209,19 & 11,89 & 135,78 & 123,89 \\
\hline \multicolumn{7}{|c|}{ Токсичные и потенциально-токсичные микроэлементы } \\
\hline $\mathrm{Al}$ & 2,77 & 12,84 & 10,07 & 1,18 & 16,99 & 15,81 \\
\hline $\mathrm{Cd}$ & 0,002 & 0,09 & 0,088 & 0,001 & 0,188 & 0,187 \\
\hline $\mathrm{Pb}$ & 0,03 & 1,69 & 1,66 & 0,038 & 4,06 & 4,02 \\
\hline $\mathrm{Sn}$ & 0,01 & 1,77 & 1,76 & 0,009 & 1,46 & 1,45 \\
\hline $\mathrm{Hg}$ & 0,1 & 2,15 & 2,05 & 0,03 & 2,3 & 2,27 \\
\hline
\end{tabular}

представлена подзолистыми почвами с большим содержанием кремниевой кислоты [6]. Соединения кремния мигрируют из почвы в поверхностные воды, создавая высокие концентрации указанного элемента. Считается, Магаданская область находится в кремниевой геохимической зоне [15].

По нашим данным, у аборигенов отмечено повышение 75 центиляна 12,4\%, у метисов - на 30,0\%, причем изменчивость содержания кремния у аборигенов выше, чем у метисов $\left(\operatorname{Lim}_{1}=209,19>\operatorname{Lim}_{2}=123,89\right)$.

Практически вся территория России является зоной йодного дефицита [16]. Повышенное поступление кремния в организм человека на фоне дисбаланса йода, кобальта может приводить к развитию аутоиммунных заболеваний (гипотиреоз) [17].

Алюминий $(\mathrm{Al})$ играет важную роль в образовании белковых и фосфатных комплексов, в процессах регенерации соединительной, эпителиальной и костной тканей, способен оказывать влияние на пищеварительные ферменты, функцию околощитовидных желез [13].Изменчивость содержания алюминия в группе метисов выше, чем в группе аборигенов $\left(\operatorname{Lim}_{2}=15,81>\operatorname{Lim}_{1}=10,07\right)$. Значение 25 центиля снижено относительно референтной величины у метисов на $39,5 \%$, у аборигенов на 53,8\%.

В настоящее время негативные последствия от дефицита алюминия в организме не установлены. Основными источниками поступления алюминия в организм являются пищевая и фармацевтическая промышленность (пищевые добавки, посуда, упаковочный материал) [18].

В Магаданской области активно ведется добыча полезных ископаемых открытым способом, что может сопровождаться загрязнением окружающей среды токсичными элементами, в частности кадмием и свинцом.

Кадмий $(\mathrm{Cd})$ относят к токсичным (иммунотоксичным) микроэлементам. В организме человека указанный элемент аккумулируется в почках, печени и двенадцатиперстной кишке. Изменчивость содержания кадмия в группе аборигенов выше, чем в группе метисов $\left(\operatorname{Lim}_{2}=0,178>\operatorname{Lim}_{1}=0,088\right)$.Отмечено снижение 25 центиля относительно референтного значения у аборигенов на 50,0\%, у метисов на 70,0\%.

Свинец $(\mathrm{Pb})$ обладает канцерогенным и тератогенным эффектом. Размах изменчивости свинца у метисов выше в сравнении с аборигенами $\left(\operatorname{Lim}_{2}=4,02>\operatorname{Lim}_{1}=1,66\right)$, на фоне общего снижения содержания свинца относительно референтных величин.

Низкое накопление кадмия и свинца в волосах аборигенов/метисов, свидетельствует о благоприятной экологической обстановке.

Олово (Sn) входит в состав гастрина, способно усиливать процессы роста. В волосах аборигенов, в отличие от метисов, изменчивость концентраций олова выше $\left(\operatorname{Lim}_{1}=1,76>\operatorname{Lim}_{2}=1,45\right)$. При этом в исследованных группах отмечено значительное снижение содержания олова в волосах: уменьшение 25 центиля относительно референтной величины превышает $80 \%$.

По данным литературы, избыток олова снижает активность иммунной системы и способно провоцировать развитие онкологических заболеваний, но некоторые оловоорганические соединения проявляют противоопухолевую активность [19, с. 223].

Pmymb (Hg) в зависимости от формы поступает в организм через легкие (металлическая элементарная ртуть) и желудочно-кишечный тракт (метилртуть). Ртуть, в основном, накапливается в нейронных клетках, печени, способна проникать через плацентарный барьер.

На территории Магаданской области население традиционно употребляет в пищу рыбу и морепродукты. Гидробионты способны накапливать ртуть поступающую с пищей и водой [20, с. 39] и, в последующем, служить источниками метилртути для человека. Считается, что волосы являются индикатором поступления метилртути [21].Содержание ртути в волосах аборигенов/метисов значительно снижено относительно биологически допустимого уровня. Значение размаха изменчивости ртути у метисов больше чем у аборигенов $\left(\operatorname{Lim}_{2}=2,27>\operatorname{Lim}_{1}=2,05\right)$.

В случае низкого накопления ртути в волосах не- 


\section{СОДЕРЖАНИЕ МИКРОЭЛЕМЕНТОВ У ЖИТЕЛЕЙ.}

обходимо учитывать, что включение неорганических форм ртутив волосы ограничено даже в случае ее повышенного поступления в организм.

Физиологическая роль ртути мало изучена. При повышенном поступлении ртути в организм имеет место нарушение иммунного статуса [22], угнетение функциональной активности зрительно нерва и сетчатки [23], деятельности высших отделов нервной системы [24].

\section{Заключение}

Таким образом, предпринятое исследование показало, незначительное отклонение содержания меди, железа, цинка у коренных малочисленных народов Северо-Востока России от среднероссийского уровня. С учетом сведений о бедности северных территорий микроэлементами, вероятно, указанное явление обусловлено адаптацией аборигенного населения к условиям Севера.

Низкие показатели тяжелых металлов: алюминия, кадмия, свинца, олова, кобальта, ртути свидетельствуют об относительном благополучии окружающей среды в плане загрязнения токсичными элементами.

Повышенное содержание кремния в волосах аборигенов и метисов согласуется с данными о принадлежности территории Магаданской области к кремневой провинции.

Размах изменчивости большинства исследованных микроэлементов выше у метисов в сравнении с аборигенами. Большая индивидуальная изменчивость микроэлемента в волосах может являться как признаком его дисбаланса организме, так и следствием индивидуальных особенностей минерального обмена.

Для дальнейшего изучения этнических аспектов минерального статуса аборигенов необходим учет половой принадлежности исследуемых жителей, а также сезонность сбора биоматериала для анализа.

\section{СПИСОК ЛИТЕРАТУРЫ:}

1. Прохоров Б.Б. Обеспечение проектов освоения новых районов медико-географической информацией // Медицинская география и здоровье. Л., 1989. C. 85-99.

2. Хаснулин В.И. Подходы к районированию территорий России по условиям дискомфортности окружающей среды для жизнедеятельности населения // Бюллетень СО РАМН. 2005. Т 3. Вып. 111. С. 113-118.

3. Ковальский В.В. Геохимическая среда и жизнь М.: Наука, 1982. 76 с.

4. Агаджанян Н.А., Коновалова Г.М., Ожева Р.Ш. Этнос, здоровье и проблемы адаптации // Новые технологии. 2010. №3. С. 93-97.

5. Манчук В.Т., Надточий Л.А. Состояние и тенденции формирования здоровья коренного населения Севера и Сибири // Бюллетень СО РАМН. 2010. Т 30, Вып. 3. С. 24-32.

6. Горбачев А.Л. Биоэлементный статус аборигенных жителей северных регионов России // СевероВосточный научный журнал. 2012. №3 (11). С. 37-45.

7. Авцын А.П., Жаворонков А.А., Риш М.А., Строчкова Л.С. Микроэлементозы человека: этиоло- гия, классификация, органопатология.М.: Медицина, 1991. 496c.

8. Старова Н.В. Природные закономерности распределения и взаимодействия химических элементов в различных биологических системах. В кн.: Проблемы экологии: Принципы их решения на примере Южного Урала / под ред. Н.В. Старовой / М.: Наука, 2003. С. $136-170$.

9. Скальный А.В. Референтные значения концентрации химических элементов в волосах, полученные методом ИСП-АЭС (АНО Центр Биотической Медицины) // Микроэлементы в медицине. 2003. Т. 4. Вып 1. С. 55-56.

10. Горбачев А.Л., Ефимова А.В., Луговая Е.А., Бульбан А.П. Особенности элементного статуса жителей различных природно-географических территорий Магаданского региона // Экология человека. 2003. №6. С. 12-16.

11.Жестяников А.Л. Дисбаланс некоторых макрои микроэлементов как фактор риска заболеваний сердечно-сосудистой системы на Севере // Экология человека. 2005. №9. С. 19 - 25.

12. Хлебникова А.Н., Петрунин Д.Д. Цинк, его биологическая роль и применение в дерматологии // Вестник дерматологии и венерологии. 2013. №6. C. 100-116.

13. Скальный А.В., Рудаков И.А. Биоэлементы в медицине. М.: Издательский дом «ОНИКС 21 век»: Мир, 2004. 272c.

14. Оберлис Д. Новый подход к проблеме дефицита микроэлементов // Микроэлементы в медицине. 2002. Т. 3. Вып. 1. С. 2-7.

15. Горбачев А.Л., Скальный А.В., Луговая Е.А. Некоторые закономерности элементного статуса жителей северных регионов России на фоне биогеохимической характеристики Севера // Вестник восстановительной медицины. 2008. №5 А (28). С. 22-25.

16. Бабенко Г.А. Микроэлементозы человека: патогенез, профилактика, лечение // Микроэлементы в медицине. 2001. Т. 2. Вып. 1. С. 2-5.

17.Сапожников С.П., Гордова В.С. Роль соединений кремния в развитии аутоиммунных процессов (обзор) // Микроэлементы в медицине. 2013. 14 (3). C. 3-13.

18. Шугалей И.В., Гарабаджиу А.В., Илюшин М.А., Судариков А.М. Некоторые аспекты влияния алюминия и его соединений на живые организмы // Экологическая химия. 2012. №6 (13). С. 172-186.

19. Федорова Н.Н., Ложниченко О.В., Коляда М.Н., Есина О.И., Алтуфьева Н.С., Н.Т. Берберова. Влияние соединений олова и тетрафенилпорфирина на морфологию селезенки крыс // Вестник СГТУ. 2005. №3 (26). С. 222-226.

20. Ким И.Н., Штанько Т.И. О содержании ртути в рыбной продукции (обзор литературы) // Гигиена и санитария. 2009. №1. С. 38-42.

21.Таций Ю.Г. О возможности использования волос в качестве биоиндикатора загрязнения окружающей среды ртутью // Вестник Тюменского государственного университета. 2013. №12. С. 158-164. 
Т.И. Прожорина, С.А. Куролап, Н.И. Якунина ЭКОЛОГО-ГЕОХИМИЧЕСКАЯ ДИАГНОСТИКА..

22. Олжаева Р.Р., Тапбергенов С.О. Особенности механизмов адаптации и резистентности организма при ртутной интоксикации // Фундаментальные исследования. 2014. №5. С. 772-775.

23. Яблонская Д.А., Мищенко Т.С. Влияние хронической ртутной интоксикации на зрительную систему // Бюл. ВСНЦ СО РАМН. 2009. №5-6. С. 64-67.

24. Моисеенко В.Г., Радомская В.И., Родомский С.М., Пискунов Ю.Г., Савинова Т.А., Леншин А.В. Интоксикация человеческого организма металлической ртутью // Вестник ДВО РАН. 2004. №3. С. 100-110.

25. Berg J.M., Shi Y. The Galvanization of biology: a growing appreciation for the roles of zinc // Science. 1996; V. 271: p. 1081-1085.

\title{
(C) 2015
}

\section{THE CONTENT OF MICROELEMENTS RESIDENTS VARIOUS ETHNIC GROUPS OF THE MAGADAN REGION}

\author{
N.V. Pokhilyuk, applicant \\ North-East State University, Magadan (Russia)
}

\begin{abstract}
The article presents the results of a study of the element status of residents of different ethnic groups (Koryak, Even, mestizo) Magadan region. By atomic emission and mass spectral analizovs inductively coupled plasma quantity content of $\mathrm{Co}, \mathrm{Cu}, \mathrm{Fe}, \mathrm{Zn}, \mathrm{Si}, \mathrm{Al}, \mathrm{Cd}, \mathrm{Pb}, \mathrm{Sn}, \mathrm{Hg}$ hair. There was a slight deviation of the content of some essential elements (copper, iron, zinc) in Aboriginal and Métis on average. It is suggested that this phenomenon is caused by adaptation to the conditions of the indigenous population of the North. These low levels of heavy metals - aluminum, cadmium, lead, tin, cobalt, mercury, indicates the relative well-being of the environment in terms of pollution with toxic elements. The higher silicon content in the hair of Aboriginal and Métis is consistent with the data that the Magadan region is silicic province. Variability of the most studied trace elements higher in the Métis compared with the natives. High individual variability of chemical elements can be the result of an imbalance element in disadaptative organism to the environment, or a manifestation of the individual characteristics of the organism. The possible consequences of deficiency and excess of trace elements in the indigenous population of the North.
\end{abstract}

Keywords: Aboriginal people of the North; trace elements; adaptation.

УДК 556.124: 574 (470.324-25)

\section{ЭКОЛОГО-ГЕОХИМИЧЕСКАЯ ДИАГНОСТИКА СОСТОЯНИЯ ГОРОДСКОЙ СРЕДЫ ПО ЗАГРЯЗНЕНИЮ СНЕЖНОГО ПОКРОВА Г. ВОРОНЕЖА}

(C) 2015

Т.И. Прожсорина, кандидат химических наук, доцент кафедры геоэкологии и мониторинга окружающей среды факультета географии, геоэкологии и туризма Воронежский государственный университет, Воронеж (Россия)

C.A. Куролап, доктор географических наук, профессор, зав. кафедрой геоэкологии и мониторинга окружающей среды факультета географии, геоэкологии и туризма Воронежский государственный университет, Воронеж (Россия) Н.И. Якунина, бакалавр 4 курса, направление «экология и природопользование» Воронежский государственный университет, Воронеж (Россия)

Аннотация. В настоящее время наиболее востребованными являются экспрессные методы контроля качества окружающей среды, которые позволяют произвести относительно быструю оценку эколого-геохимической обстановки. Один из таких методов основан на использовании снежного покрова. Снег обладает высокой сорбционной способностью и представляет собой информативный объект при выявлении техногенного загрязнения городской среды. В работе приведены результаты исследования химического состава снежного покрова, выпавшего в г. Воронеже в течение зимы 2015 г. Пробы снега были отобраны в период, предшествующий снеготаянию, в различных функциональных зонах города. С целью выявления степени техногенной нагрузки на различные районы г. Воронежа, был сделан сравнительный анализ полученных результатов:

- по данным фактического присутствия загрязняющих веществ в атмосферных осадках для исследуемых функциональных зон;

- по рассчитанным коэффициентам концентрации химических элементов для исследуемых проб снега.

По степени минерализации и содержанию пыли в снеге можно судить о «техногенном давлении» на среду. Поэтому сравнительный анализ степени загрязненности снега в различных функциональных зонах города проводили по двум показателям химического состава - общая минерализация и взвешенные частицы (пыль). 